\title{
Macroinvertebrate assemblages on reed beds, with special attention to Chironomidae (Diptera), in Mediterranean shallow lakes
}

\author{
Maria Sahuquillo*,1, Maria Rosa Miracle ${ }^{1}$, Maria Rieradevall ${ }^{2}$ and Riyzard Kornijów ${ }^{3}$ \\ ${ }^{1}$ Dept. de Microbiologia i Ecologia. Universitat de València. 46100 Burjassot (València) Spain \\ 2 Dept. de Ecologia. Universitat de Barcelona. 08007 Barcelona. Spain \\ ${ }^{3}$ Dept. Hydrobiol. Ichthyobiol. University of Agriculture in Lublin. 20-950 Lublin, Akademicka 13, Poland. \\ *Corresponding author: maria.sahuquillo@uv.es
}

Received: $15 / 11 / 06$

Accepted: $13 / 5 / 08$

\begin{abstract}
Macroinvertebrate assemblages on reed beds, with special attention to Chironomidae (Diptera), in Mediterranean shallow lakes

Macroinvertebrates associated to reed-beds (Phragmites australis) in six shallow natural water bodies along the $220 \mathrm{~km}$ of coast of the Comunidad Valenciana (Spain) were studied. These sites were selected to reflect different trophic states, but also, and due to the natural variability of mediterranean wetlands, they greatly differ in salinity and hydroperiod. To unify the sampling, reed bed was chosen to provide data from a habitat common to all wetlands, including the most eutrophic ones where submerged macrophytes have disappeared due to water turbidity. Individual submerged stems of Phragmites australis were sampled along with the surrounding water. The animal density found refers to the available stem surface area for colonization. Forty-one taxa were recorded in total, finding Chironomidae to be the most important group, quantitatively and qualitatively. In freshwater sites it was observed an increase in macroinvertebrate's density at higher trophic states. Nevertheless each studied region had a different fauna. The PCA analysis with macroinvertebrate groups distinguished three types of environment: freshwaters (characterized by swimming insect larvae, collectors and predators, oligochaetes and Orthocladiinae), saline waters (characterized by crustaceans and Chironominae) and the spring pool, which shares both taxa. Chironomids were paid special attention for being the most abundant. A DCA analysis based on the relative abundance of Chironomids reveals salinity as the main characteristic responsible for its distribution, but trophic state and hydrological regime were also shown to be important factors.
\end{abstract}

Key words: Macroinvertebrates, Phragmites australis, chironomids, Mediterranean wetlands.

\section{RESUMEN}

Comunidades de macroinvertebrados asociados al carrizo en humedales mediterráneos, con especial atención a los Chironomidae (Diptera)

Se han estudiado los macroinvertebrados asociados a la vegetación de carrizo (Phragmites australis) en seis lagunas someras a lo largo de los $220 \mathrm{~km}$ de costa de la Comunidad Valenciana (España). Las lagunas se eligieron de manera que se contemplasen diferentes estados tróficos, pero además y reflejando la natural variabilidad de los humedales mediterráneos, presentan importantes diferencias en cuanto al hidroperiodo y la salinidad. Para unificar el muestreo, se eligio el carrizo por ser un elemento común en todos los humedales, incluso los más eutróficos en los que los macrófitos sumergidos han desaparecido debido a la turbidez del agua. Para cada muestra se toma individualmente la parte sumergida de una planta de Phragmites australis junto con el agua circundante. La densidad de animales encontrados se refiere a superficie colonizable del tallo de la planta. En total se han encontrado 41 taxones, siendo Chironomiidae el grupo más importante tanto cuantitativa como cualitativamente. En las lagunas de agua dulce, se observó un aumento de la densidad de macroinvertebrados en los niveles troficos mayores. Sin embargo cada zona de estudio tiene una fauna diferente. El análisis PCA de los grupos de macroinvertebrados diferencia tres tipos de ambientes: aguas dulces (caracterizados por larvas nadadoras de insectos recolectores y depredadores, oligoquetos y orthocladinos), aguas salobres (caracterizadas por la presencia de crustáceos y Chironomiinae) y el "ullal" o surgencia de agua que comparte taxones de los dos grupos anteriores. Se ha prestado especial 
atención al grupo de quironómidos por ser los más abundantes. Un análisis DCA basado en la abundancia relativa de las especies de quironómidos, muestra la salinidad como la principal característica responsable de su distribución, siendo luego el estado trófico y el régimen hidrológico factores también importantes.

Palabras clave: Macroinvertebrados, Phragmites australis, quironómidos, humedales mediterráneos.

\section{INTRODUCTION}

Reed beds are the most common and dominant type of vegetation on the littoral zone of most shallow lakes, even the most eutrophic ones where submerged macrophytes could have disappeared due to increased turbidity. They represent an essential part in wetlands and lake littoral and play a crucial role as shelter and substrata for food resources for many organisms, from macroinvertebrates to fish and birds. In addition,their litter supports an important detritivorous biocenosis (Varga, 2001). Although they have undoubted importance, the biological community associated to reed stems in Mediterranean wetlands is scarcely known.

In addition, its simple architecture enables the colonisable surface area to be measured easily. Consequently, submerged reed stems are an interesting habitat to measure quantitative and comparable variables of the biological community for different types of lakes. For this reason, the study of their macroinvertebrate community has been proposed as a useful tool in the determination of the ecological status of wetlands and shallow lakes (Kornijów \& Kairesalo, 1994). The present paper is a further development of the data collected for a pan-European project (ECOFRAME, Moss et al., 2003) which attempted to test a classification system for shallow lakes in the field according to the requirements of the European Water Framework Directive (WFD). Among a wide range of biological variables several macroinvertebrates indexes were tested in this project, including some based on macroinvertebrates of reed beds.

This study presents the quantitative and qualitative results for the macroinvertebrates associa- ted with emergent macrophytes (Phragmites australis) in six shallow water bodies at the Mediterranean coast of the Iberian Peninsula. Since chironomids were the dominant macroinvertebrate group, they were studied in more detail and at the finest possible taxonomic level.

\section{STUDY SITES}

Macroinvertebrates associated to reeds were sampled in six shallow water bodies located in protected wetlands along the $220 \mathrm{~km}$ of the Mediterranean coast of Valencia, Spain in June and July 2001. The same sites were studied for the mentioned multidisciplinary project ECOFRAME and are described elsewhere (Moss et al., 2003; Blanco et al., 2003; Sahuquillo et al., 2007; Poquet et al., 2008).

All sites were very shallow (less than $3 \mathrm{~m}$ in depth) and they were chosen due to their oligohypereutrophic gradient: Albufera being hypereutrophic, Cap de Terme eutrophic, Hondo mesotrophic, and the rest oligo-mesotrophic (Xeresa, Baldoví and Cabanes). In addition, and reflecting the natural variability in the Mediterranean wetlands, the sites differed in other environmental characteristics. All sites are small shallow lakes, except the large Albufera lagoon; the names used here correspond with the general names of the wetland where they are located. Two sites had brackish waters: Hondo and Cabanes, the former one mainly due to evaporation and soil characteristics and the latter to marine influence. With respect to hydrology, Baldoví is a spring fed pond, which has a high subterranean karstic water flow of constant temperature and mineral composition, with some marine influence due to 
sea closeness. The flow is also relatively important in Cap de Terme, excavated for drainage to transform the marshland into agricultural fields; and in the Albufera lagoon (Vicente \& Miracle, 1982). Both sites received important agricultural inflows and Albufera also received industrial and domestic waters (only partly purified). Cabanes is an excavated pond for peat extraction with permanent water and without important inflows. Xeresa and Hondo represent hydrologically fluctuant systems because they are shallow and have reduced water inflows that determine their semi-permanent character; they can dry up at the end of summer during very dry years. All sites have extensive reed belts.

Table 1 summarizes the most important features of the studied sites and the values of some limnological variables measured simultaneously during the samplings of reeds stems.

\section{METHODS}

\section{Macroinvertebrate sampling}

Invertebrates from submerged reed (Phragmites australis) stems were sampled in four areas at each one of the study sites from June 28 to July 3,2001 . The areas were chosen randomly across sites and stems were taken with a boat from the water edge of each reed bed. The sampling method involves collecting each individual reed stem and surrounding water by means of a transparent plastic tube $(5 \mathrm{~cm}$ internal diameter and $75 \mathrm{~cm}$ high) with a cutting devise and a filter at the bottom (Kornijów \& Kairesalo, 1994). After cutting the aerial part of the stem, the tube was lowered into the water surrounding the stem, the top of the tube was closed with a cork and the stem cut at the lower base, then the stem floated and the tube was closed with a $250 \mu \mathrm{m}$ sieve cup, which allowed us to pick up the individual stem and filter the surrounding water. Five stems were collected separately within each area but pooled together to give one sample per area. Right after sampling the larger individuals were individually picked out and preserved in $70 \%$ ethanol. The stems were then rinsed thoroughly with water and this water together with the rest of the sample was filtered through a sieve of a smaller size $(100 \mu \mathrm{m})$ to collect all the other animals, which were preserved in the same way. Macroinvertebrates were manually sorted, identified and counted under a stereoscope.

The length and diameter of each stem collected was measured to calculate their total area and express the density of animals per $\mathrm{m}^{2}$ of stem surface area.

Table 1. Main characteristics of studied sites during sampling dates in 2001. Sites are ordered from North to South. Características principales de los lugares de estudio durante el muestreo ordenados por latitud.

\begin{tabular}{|c|c|c|c|c|c|c|c|}
\hline & $\begin{array}{c}\text { UTM } \\
\text { X } \\
\text { Y }\end{array}$ & $\begin{array}{l}\text { Area } \\
\text { (ha) }\end{array}$ & $\begin{array}{c}\text { Conductivity } \\
(\mu \mathrm{S} / \mathrm{cm})\end{array}$ & $\begin{array}{l}\text { Secchi } \\
\text { (m) }\end{array}$ & $\begin{array}{l}\text { Chl- } a \\
(\mu \mathrm{g} / \mathrm{l})\end{array}$ & $\begin{array}{l}\text { Temp } \\
\left({ }^{\circ} \mathrm{C}\right)\end{array}$ & Date \\
\hline CABANES (Charca del Pozo) & $\begin{array}{r}31 \mathrm{~T} 261913 \\
4452142\end{array}$ & 2.3 & 11840 & Bottom & 1.8 & 24.2 & 2 jul \\
\hline ALBUFERA lagoon & $\begin{array}{r}\text { 30S } 730524 \\
4356507\end{array}$ & 2200 & 2230 & 0.37 & 169.7 & 28.3 & 28 jun \\
\hline BALDOVÍ & $\begin{array}{r}\text { 30S } 731577 \\
4347997\end{array}$ & 0.5 & 3050 & Bottom & 1.2 & 30.6 & 1 jul \\
\hline CAP DE TERME & $\begin{array}{r}\text { 30S } 739977 \\
4326566\end{array}$ & 3.5 & 2660 & 0.4 & 86.5 & 29.5 & 29 jun \\
\hline XERESA (Rini) & $\begin{array}{r}30 S 743260 \\
4321856\end{array}$ & 0.1 & 2590 & Bottom & 5.7 & 33 & 29 jun \\
\hline HONDO (Charca Sud-Oeste) & $\begin{array}{r}30 S 696925 \\
4229649\end{array}$ & 11.0 & 18480 & Bottom & 35.5 & 31.7 & 3 jul \\
\hline
\end{tabular}




\section{Macroinvertebrate and Chironomidae identification}

In all the samples, invertebrates were identified to the following taxonomic levels: Turbellaria, Naididae, other Oligochaeta, Gastropoda, Amphipoda, Isopoda, other Crustacean, Hydracarida, Zygoptera, Anisoptera, Ephemeroptera, Heteroptera, Lepidoptera, Trichoptera, Tanypodinae, Orthocladiinae, Chironominae, other Chironomidae, and Ceratopogonidae, following the ECOFRAME scheme that looked for a balance between the information required for a quality index and the time needed for identification and counting.
In two samples per site, individuals were counted at species level and identified when possible, with special attention to chironomids. Chironomid larval muscle mass and tissues that could have made identification difficult were removed with a $\mathrm{KOH}$ solution warmed to $85^{\circ} \mathrm{C}$ for 20 minutes, They were then dehydrated in $70 \%$ and $96 \%$ ethanol successively, and mounted in permanent slides in Euparal media. Chironomids were identified at the lowest taxonomical level possible following Hirvenoja (1981), Wiederholm (1983), and Schmid (1993). Pupal skins were used to validate larval identifications (Langton, 1991). Coding names in the

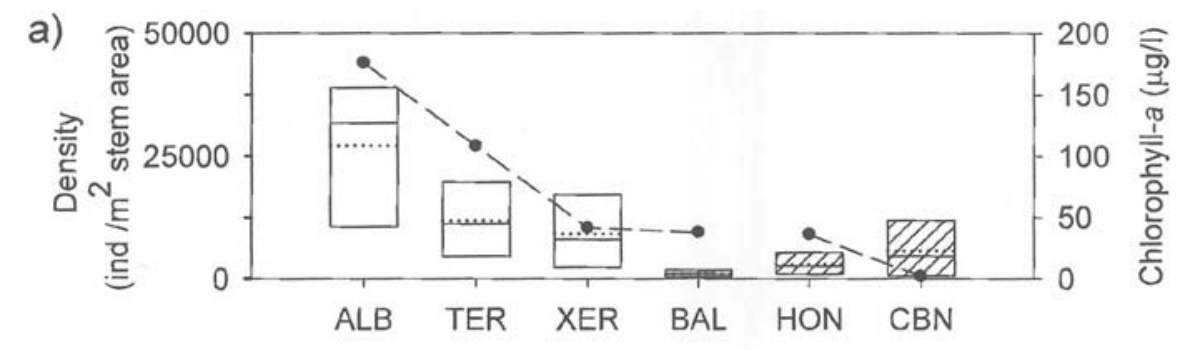

b)

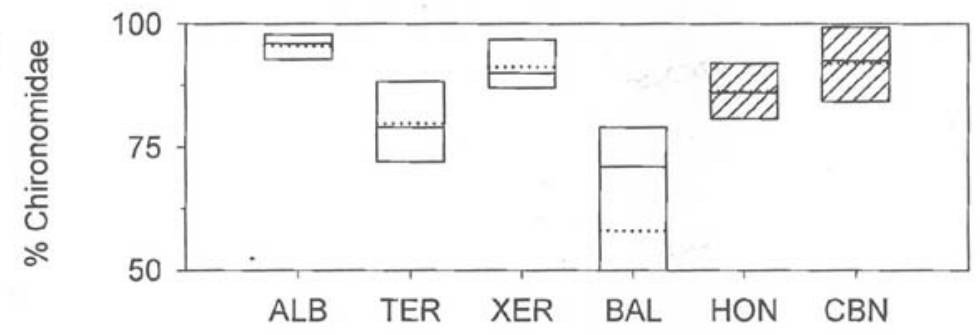

c)

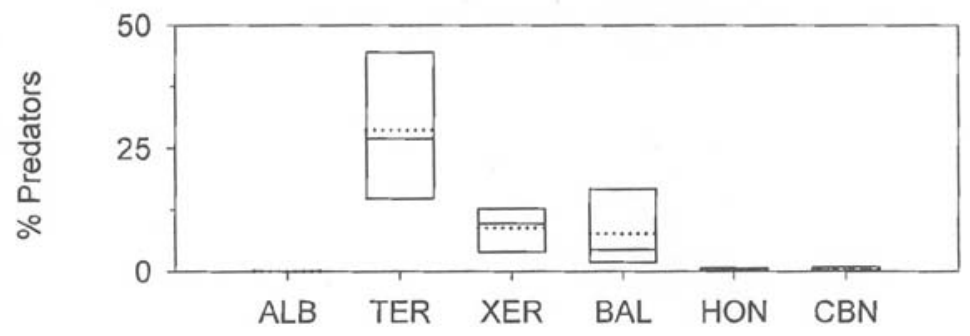

Figure 1. (a) Densities of macroinvertebrates associated to reed stems (Phragmites australis) (box-plots) and planktonic chlorophyll- $a$ (dots and dash line), (b) Relative abundance of chironomids (\%) and (c) Relative abundance of predators (\%) in six Mediterranean water bodies ordered with decreasing trophic status. White plots: freshwater sites, striped ones: brackish sites. Box-plots with mean $=$ dashed line, median $=$ solid line, upper limit $75^{\text {th }}$ percentile and lower limit $25^{\text {th }}$ percentile, $n=4$ samples per site with five stems per sample. Sites are ordered with increasing trophic status, from eutrophic (on the left) to oligotrophic for each group of sites. (a) Densidades de macroinvertebrados asociados al carrizo (Phragmites australis) (box-plots) y clorofila-a planctónica (puntos y línea discontinua), (b) Abundancia relativa de quironómidos (\%) y (c) Abundancia relativa de macroinvertebrados depredadores (\%) en seis lagunas mediterráneas separadas en dos grupos, aguas dulces en blanco y salobres en rayado, y situadas en orden decreciente de eutrofia dentro de cada grupo. Box-plots representan: la media= línea discontinua, la mediana = línea continua, los percentiles 25 y 75 = límites de la caja; 4 muestras por laguna con 5 cañas por muestra. ALB, Albufera; TER, Cap de Terme; XER, Xeresa; BAL, Baldoví; HON, Hondo and CBN, Cabanes. 
figures presented followed Schnell et al. (1999). At the same time direct Chironomid gut content observations were performed.

\section{Data analysis}

Density differences between sites were tested using one-way ANOVA. Number of taxa (taxon richness) and H' diversity index (Shannon \& Wiener) were calculated with samples analyzed at the species level.

A Principal component analysis (PCA) was applied to standardized data consisting of arcsen $\sqrt{ }$ transformed proportions of macroinvertebrate groups. The number of variables was reduced by grouping taxa at a high taxonomic level for the non-predators: Oligochaeta, Gastropoda Crustaceans, Hydracharida, Ephemeroptera/Trichoptera, Orthocladiinae, and Chironominae. Due to the importance of the feeding habits, predator taxa were treated separately in three groups: non-dipteran insect predators (Zygoptera, Anisoptera, Heteroptera, Lepidoptera, and the Ecnomus genus within Trichoptera), dipteran predators (Ceratopogidae and Tanypodinae), and small predators (hydra and microturbellarians).

\section{RESULTS}

In the six studied sites, densities of animals recorded on the reed ranged between 260 and $39000 \mathrm{ind} / \mathrm{m}^{2}$ of stem surface area (Fig. 1a). Individual stems sampled had about 0.04-0.13 $\mathrm{m}^{2}$ surface area and these values can be used to estimate numbers per stem. In freshwater sites, density differences according to trophic state categories were highly significant (One way ANOVA resulted significantly different d.f. $=3$, $F=5.069, p<0.01)$. Densities increased with eutrophy; the more eutrophic sites, Albufera and Cap de Terme, had clearly higher densities of macroinvertebrates than the oligotrophic sites (Baldoví and Xeresa) (Fig. 1a). Densities were generally lower in brackish waters than in the freshwater sites.

A relation was found between increasing density and percentage of chironomids but only

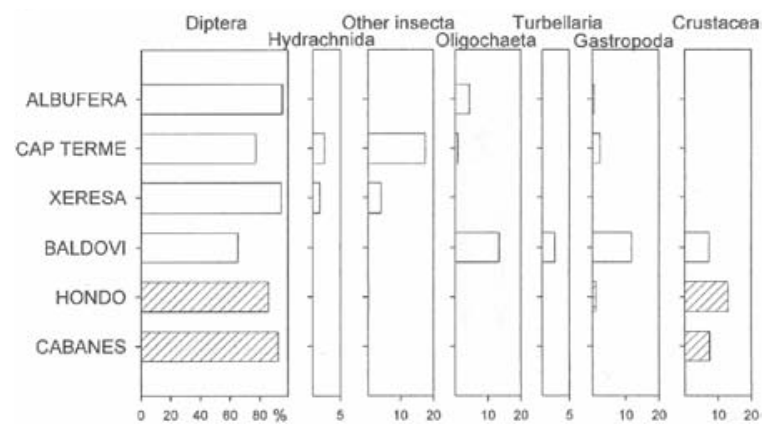

Figure 2. Relative abundance ( $\%$ ) of main macroinvertebrate groups recorded in $P$. australis stems in six Mediterranean water bodies. Freshwater sites in white bars and saline sites in striped bars. Abundancia relativa (\%) de los principales grupos de macroinvertebrados recolectados en carrizos (P. australis) en seis lagunas mediterráneas. Histogramas blancos: lagunas de agua dulce; rayados: salobres.

when similar systems were compared (Fig. 1b). In permanent freshwater aquatic systems, like Albufera, Cap de Terme and Baldoví, the sites with higher eutrophication had higher macroinvertebrate densities mainly due to higher chironomid densities. In the brackish sites the highest density is also related to the highest chironomid proportion. Predators were more important in freshwater and less eutrophic sites (Fig. 1c).

In all samples and sites, chironomids were the dominant group. The total dipteran larvae comprised between 60 and $100 \%$ of the total individuals found (Fig. 2). Within dipterans all individuals belonged to Chironomidae, except in Xeresa where a few Ceratopogonidae $(0.5 \%$ relative abundance) were recorded. In freshwaters sites, non dipteran insects and oligochaetes were also important, the former being more abundant in Cap de Terme and Baldoví, and the latter in Albufera. In brackish sites, the second group in abundance was crustacea. Nevertheless, none of these groups reached relative densities over $20 \%$. The freshwater spring pool Baldoví shares characteristic taxa with both types of waters, due to its high chlorine levels and marine proximity.

Overall, forty-one taxa were identified (Table 2 and Table 3). Species richness per site ranged from 6 to 15, being higher in the permanent and not hypertrophic freshwater sites; Cap de Terme and Baldoví with 15 and 14 taxa, respectively, were the highest. The highest diversity values were also recorded on these sites (Fig. 3). 
Table 2. Macroinvertebrate taxa associated to reed stems in six Mediterranean water bodies in 28 June-3 July 2001 . The mean abundance (ind $/ \mathrm{m}^{2}$ stem surface area) calculated over four samples per site ( 5 stems per sample). Taxones de macroinvertebrados asociados al carrizo en seis lagunas Mediterráneas. Se indica la abundancia media (ind/ $\mathrm{m}^{2}$ de superficie de caña) de cuatro muestras por sitio (5 cañas por muestra).

\begin{tabular}{|c|c|c|c|c|c|c|}
\hline & Albufera & Cap Terme & Xeresa & Baldoví & Hondo & Cabanes \\
\hline Hydra & & & & 9 & & \\
\hline Microturbellarians & & & & 26 & & \\
\hline \multicolumn{7}{|l|}{ OLIGOCHAETA } \\
\hline Chaetogaster limnaei Baer & & & & 96 & & \\
\hline Chaetogaster sp. & 524 & & & & & \\
\hline Nais sp. & 668 & 91 & 15 & 17 & & \\
\hline Pristina sp. & & & & 16 & & \\
\hline Aelosoma sp. & & & & 20 & & \\
\hline
\end{tabular}

\section{GASTROPODA}

Physella acuta Draparnaud

163

Melanopsis tricarinata Bruguière

Theodoxus fluviatilis (Linnaeus)

Ferrissia wautieri Mirolli

96

Semisalsa sp.

Valvata piscinalis Müller

Planorbidae

CRUSTACEA

Gammarus aequicauda Martynov

Echinogammarus pacaudi Hubault \& Ruffo

Lekanesphaera hookeri Leach

Dugastella valentina Ferrer Galdiano

Palaemonetes zariquieyi Sollaud

Heterotanais oerstedi Kroyer

8

\begin{tabular}{|c|c|c|c|c|c|c|}
\hline HYDRACHNIDA & & 526 & 232 & & & \\
\hline \multicolumn{7}{|l|}{ ODONATA } \\
\hline Ischnura elegans (Van der Linden) & & 1098 & & & & \\
\hline Other Coenagrionidae & & & 37 & & & 12 \\
\hline Sympetrum fonscolombei (Selys) & & & 51 & & & \\
\hline Other Anisoptera & & 3 & & & & \\
\hline \multicolumn{7}{|l|}{ EFEMEROPTERA } \\
\hline Caenis luctuosa (Burmeister) & & & 284 & & & \\
\hline Clöeon dipterum (Linnaeus) & & 139 & & & & \\
\hline \multicolumn{7}{|l|}{ HETEROPTERA } \\
\hline Plea minutissima Leach & & 22 & & & & \\
\hline Micronecta sp. & 10 & & & & 4 & \\
\hline \multicolumn{7}{|l|}{ LEPIDOPTERA } \\
\hline Lepidoptera & 2 & & & & 4 & \\
\hline \multicolumn{7}{|l|}{ TRICHOPTERA } \\
\hline Ecnomus sp. & & 804 & & & & \\
\hline Other Trichoptera & 27 & & & & & \\
\hline CERATOPOGONIDAE & & & 39 & & & \\
\hline ORTHOCLADIINAE & 24680 & 5962 & 8147 & 706 & 6 & 2602 \\
\hline CHIRONOMINAE & 1083 & 3171 & 102 & 2 & 2524 & 2729 \\
\hline TANYPODINAE & & 4 & 349 & & & \\
\hline
\end{tabular}



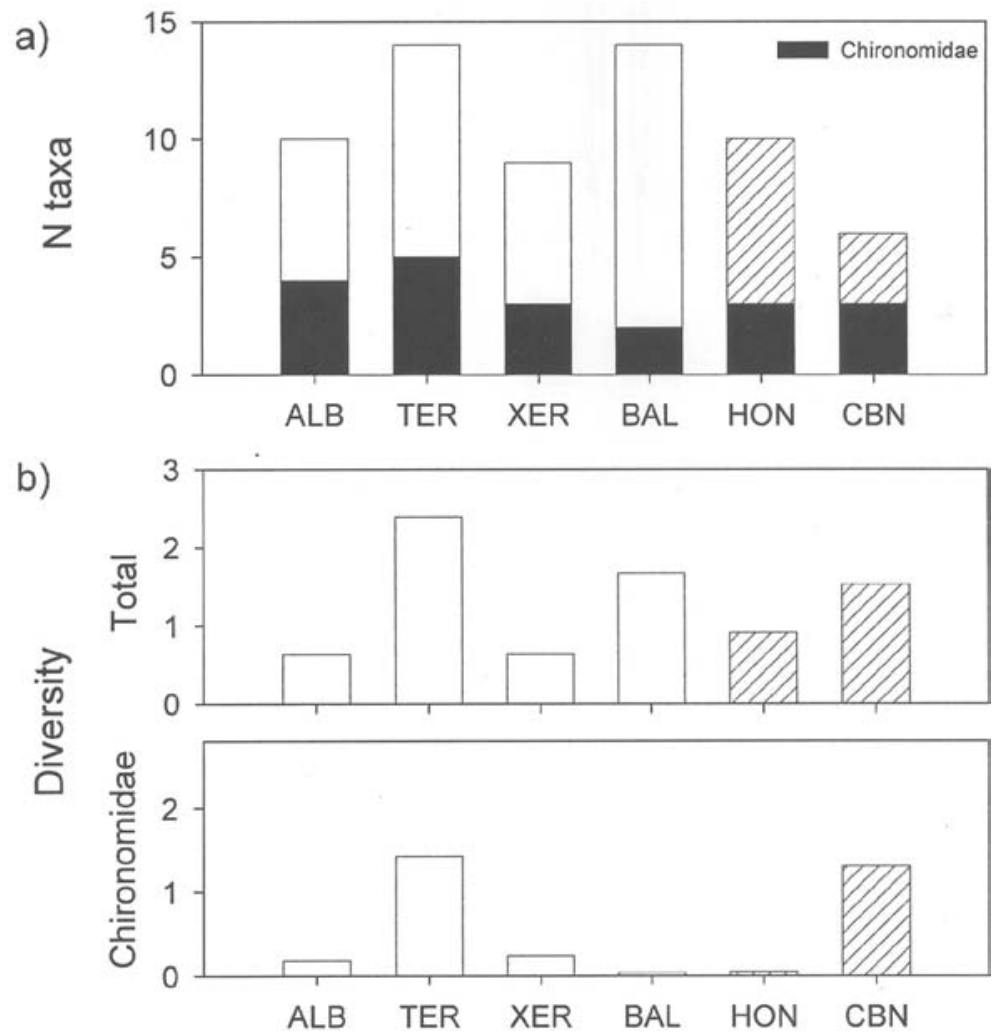

Figure 3. (a) Number of species for total macroinvertebrate community and for Chironomidae and (b) $\mathrm{H}^{\prime}$ diversity of total macroinvertebrate community and of Chironomidae associated to reed stems in six Mediterranean water bodies. Histograms represent mean of two samples per site. In (a) black = Chironomidae and white or striped = other macroinvertebrates. Striped histograms correspond to brackish and unstriped to freshwater localities. (a) Número total de especies de macroinvertebrados y de quironómidos y (b)

$H^{\prime}$ diversidad del total de macroinvertebrados y de la familia de los Chironomidae encontrados en el carrizo en seis lagunas mediterráneas. Los histogramas representan la media de dos muestras por laguna. En a) el fondo negro indica quironómidos y en blanco o rayado otros macroinvertebrados. Histogramas blancos: lagunas de agua dulce; rayados: salobres.

A PCA analysis applied to the proportions of macroinvertebrate groups distinguished three kinds of environment: freshwater, brackish waters and the spring pool (Fig. 4). The first two axes explained $63 \%$ of the variation (38\% and $25 \%$ first and second axes respectively). The main variability is due to salinity. Brackish water bodies are positioned on the right side as well as Chironominae, crustaceans and gastropods, whereas Orthocladiinae together with big insects (Ephemeroptera, Odonata) and Hydracharida, more characteristic of freshwater bodies, are placed on the opposite side. However, Albufera is placed in the centre and the spring pool Baldoví is positioned on the positive side because of its abundant crustacean fauna. The second axis is again related to salinity and separates mainly the brackish water bodies (with higher negative scores) from Baldoví (with higher positive scores). Chironominae and Orthocladiinae are again in opposite positions. On the other hand Oligochaeta and small predators have high positive values on this axis.

Chironomid assemblages are of special interest because they are the most abundant group in this habitat and, in the present study, they had distinct species compositions characterizing the different sites (Table 3). Orthocladiinae dominated in freshwater sites while Chironominae were dominant in the brackish water ones, but belonging to the Chironomini tribe in Hondo, and to Tanitarsini in Cabanes. In permanent freshwater bodies Cricotopus sylvestris was dominant and was not present in any of the brackish water sites. 
Table 3. Chironomid species associated to reed stems in six Mediterranean water bodies sampled in 28 June-3 July 2001 . The mean abundance (ind $/ \mathrm{m}^{2}$ stem surface area) calculated over two samples per site ( 5 stems per sample). Feeding mechanism $(\mathrm{P}=$ predator; $\mathrm{CG}=$ collector-gatherer) and dominant food resource are also indicated after gut content examination. Especies de quironómidos asociadas al carrizo en seis lagunas mediterráneas muestreadas entre el 28 de junio y el 3 de julio de 2001. Se indica la abundancia media (ind $/ \mathrm{m}^{2}$ de superficie de caña) de dos muestras por laguna (5 cañas por muestra), así como los mecanismos de alimentación $(P=$ depredator; $C G=$ recolector-ramoneador) y la principal fuente de alimento tras la observación directa del contenido intestinal .

\begin{tabular}{|c|c|c|c|c|c|c|c|}
\hline & Albufera & $\begin{array}{c}\text { Cap } \\
\text { Terme }\end{array}$ & Xeresa & Baldoví & Hondo & Cabanes & $\begin{array}{c}\text { Feeding } \\
\text { mechanism } \\
\text { (dominant food) }\end{array}$ \\
\hline \multicolumn{8}{|l|}{ TANYPODINAE } \\
\hline Ablabesmyia monilis (Linnaeus) & & & 508 & & & & $\mathrm{P}($ C. flavocinctus $)$ \\
\hline \multicolumn{8}{|l|}{ ORTHOCLADIINAE } \\
\hline Corynoneura & & 6 & & & & & CG (diatoms) \\
\hline Cricotopus flavocinctus (Kieffer) & & 214 & 13381 & & 5 & 4707 & $\mathrm{CG}$ (diatoms) \\
\hline Cricotopus (Isocladius) sylvestris (Fabricius) & 19271 & 8247 & & 1169 & & & CG (detritus) \\
\hline \multicolumn{8}{|l|}{$\overline{\text { CHIRONOMINI }}$} \\
\hline Chironomus gr. luridus & 4992 & & & & & & CG (detritus) \\
\hline Chironomus/Einfeldia & & & & & 3760 & & $\mathrm{CG}$ (diatoms) \\
\hline Dicrotendipes pallidicornis (Goetghebuer) & & 2058 & & & & 771 & CG (diatoms) \\
\hline Parachironomus & 7 & 3002 & & 5 & & & $\mathrm{P}$ \\
\hline \multicolumn{8}{|l|}{ TANYTARSINI } \\
\hline Paratanytarsus & 7 & & & & & & CG (detritus) \\
\hline Tanytarsus & & & 18 & & 14 & 4916 & $\mathrm{CG}$ (diatoms) \\
\hline
\end{tabular}
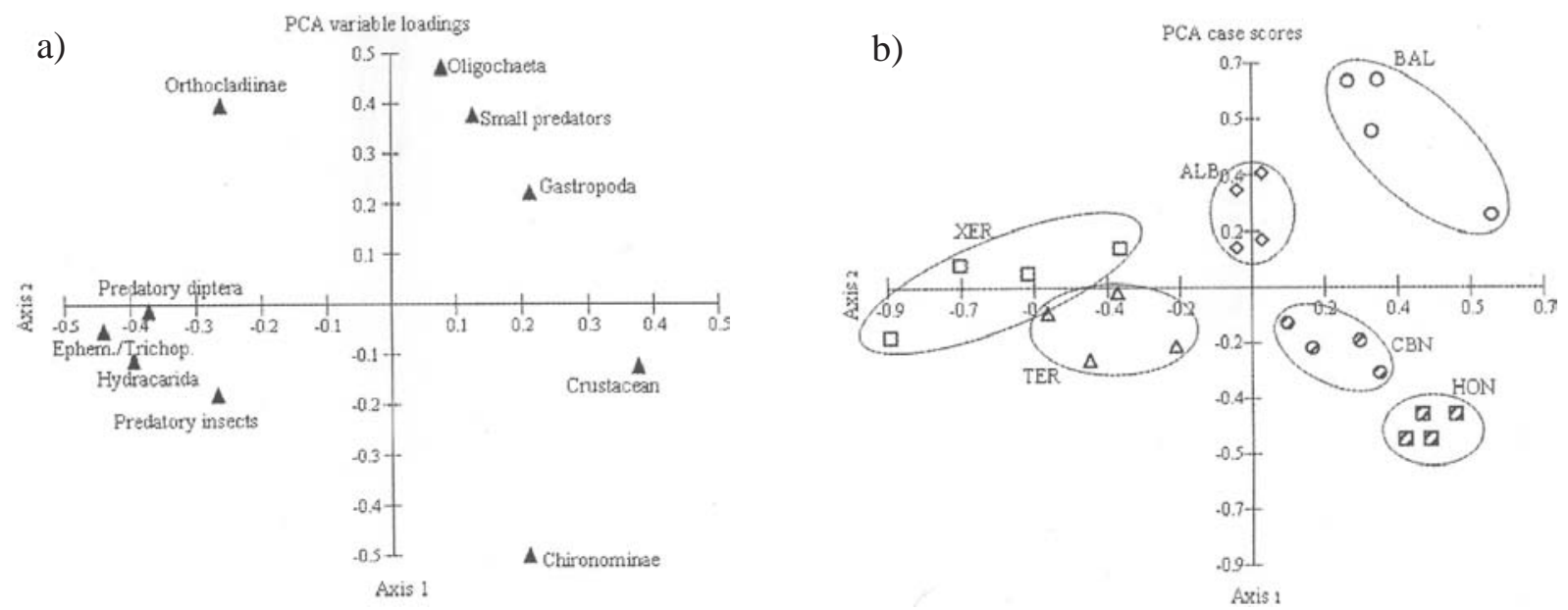

Figure 4. Principal components analysis (PCA) applied to the proportions of different groups of macroinvertebrates collected on reed stems in six Mediterranean water bodies (4 samples per water body). (a) Loadings of macroinvertebrate groups and (b) sample-scores grouped by water-bodies are represented in the space of the first two principal components. Análisis de componentes principales (PCA) aplicado a las proporciones de grupos de macroinvertebrados asociados al carrizo en seis lagunas mediterráneas (4 muestras por sitio). Representación en el espacio de las dos primeras componentes princiales de (a) losgrupos de macroinvertebrados y (b) muestras agrupadas por lagunas.

However, it was not observed in the less eutrophic and semipermanent Xeresa site where Cricotopus flavocinctus dominated, the latter species was also important in Cabanes, the more oligotrophic of the brackish water sites. The accom- panying secondary species were different in each of the studied water bodies (Table 3). The DCA, applied to the relative abundances of chironomid species, indicated that salinity was the most important feature responsible for chironomid spe- 


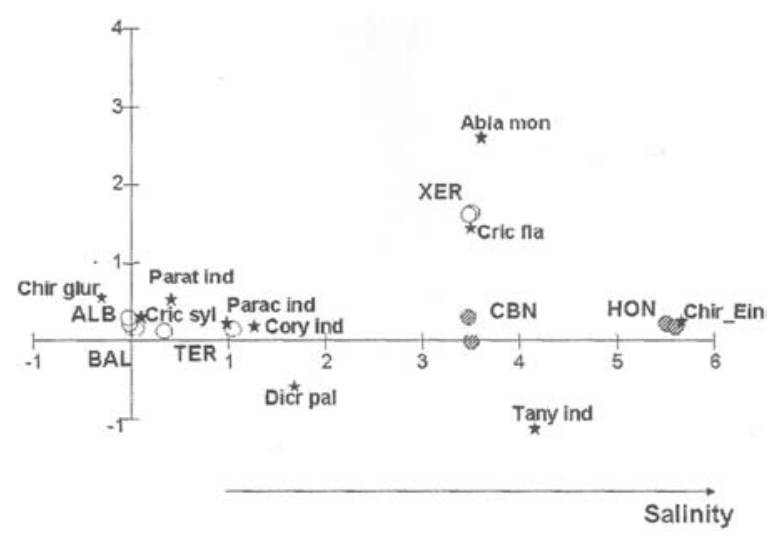

Figure 5. Detrended correspondence analysis (DCA) applied to the proportions of chironomid species associated to reed samples in six Mediterranean water bodies. Byplot of axis 1 and 2 of species and samples (two per water body). Análisis de correspondencias Detrended (DCA) de las proporciones de especies de quironómidos en el carrizo en seis lagunas mediterráneas (dos muestras por sitio). Representación de casos y variables sobre los ejes 1 y 2. Water bodies (Lagunas): ALB, Albufera; TER, Cap de Terme; XER, Xeresa; BAL, Baldoví; HON, Hondo and CBN, Cabanes. Species (Especies): Abla mon: Ablabesmyia monilis; Cric fla: Cricotopus flavocinctus; Cric syl: Cricotopus (Isocladius) sylvestris; Chirglur: Chironomus gr. luridus; Chir-Ein: Chironomus/Einfeldia; Dicr pal: Dicrotendipes pallidicornis; Paracind: Parachironomus; Paratind: Paratanytarsus; Tanyind: Tanytarsus.

cies distribution, whereas trophic state had a less apparent role (Fig. 5). Tanytarsini and Einfeldia were placed on the positive extreme of the first axis with the brackish water sites, whereas Cricotopus sylvestris and Chironomus gr. luridus were placed near the origin where the permanent freshwater sites also came grouped together. The second axis of DCA separates Xeresa with a more fluctuating water level (which can dry up in some years) from the rest of the sites, thus indicating the importance of hydrological regime.

\section{DISCUSSION}

The sampling method applied proved suitable to study animal composition attached to reed stems. However, some species inhabiting vegetation beds are good swimmers and probably escaped from this trap, therefore their presence could have been underestimated. The macroinvertebrate community associated with plants was studied using a hand net in the same sites the year before (Sahuquillo et al., 2007). The number of taxa recorded was higher using the hand net among emergent plants, mainly reed stems, as well as submerged ones (54 taxa), rather than with the method used in the present study. Moreover, in the present study more than $90 \%$ of the individuals corresponded to chironomids; while in hand net samples this group represented about $40 \%$. The difference in composition in the present study was mainly due to the scarce presence of big gastropod taxa and good swimmers, such as crustaceans or coleopterans. Several studies in small ponds support that reed beds present similar macroinvertebrate assemblages and species richness as other plant beds (Dvorak \& Best, 1982; Van de Meutter et al., 2005), although relative abundance could differ. García-Criado \& Trigal (2005) found a higher relative abundance of naidid oligochaetes and Orthocladiinae in emergent macrophytes. The reduced number of species recorded in our study could be related to the small sample size of the collector, which does not collect the surrounding free water. The most delicate part of the method is the manipulation when cutting the aerial part of the stem at the surface of the water, as some species, like big gastropods, can fall down or swim away. In this respect the precaution taken by Oertly et al. (1995), with a comparable method for Typha latifolia, was to cut this aerial part the day before sampling (or some time before) so that swimming species could resettle. Taking this measure should improve the method. However the aim of this study was not to describe the whole lake's macroinvertebrate community but quantify the populations attached to reed stems.

Despite the differences in community composition among sites, the density of individuals responded to eutrophication with the number of individuals increasing in line with trophic state, as expected, but this was only clear in the freshwater sites. On comparing lakes of different trophic levels, most studies found a density increase with trophic status (Kornijów, 1989, Pieczyńska et al., 1999). Moreover, Pieczyńska et al. (1999) also pointed out a chironomid increase in li- 
ne with macroinvertebrate density increase. In our results, in freshwater permanent sites (ALB, TER, BAL) trophic state showed also a clear direct relationship with both density and relative abundance of chironomids. However, in the two brackish sites this relationship was not observed. In this case the community composition was quite different: Hondo was dominated by the larger Chironomus/Einfeldia while in Cabanes the most frequent chironomid were minute individuals of $C$. flavocintus. Therefore total biomass was indeed lower in the oligotrophic site. The increase in eutrophication had repercussions firstly on an increase in density, mainly due to chironomids and oligochaetes that feed mostly on algae or/and detritus, and secondly, in a decrease in the number of taxa with loss of predators. In Cap de Terme, despite high chlorophyll-a concentrations, an important biomass of submerged macrophytes is still maintained, which supports a wide range of taxa including many predators (Zygoptera and Trichoptera being abundant). With respect to Oligochaeta, commonly used for pollution surveillance (Learner et al, 1978), a finer taxonomic level could improve the assessment of the ecological status, since some opportunistic species may rapidly increase in abundance over a relatively short period of time, like Nais does, and are abundant in hypertrophic sites (like Albufera), while other species living in oligotrophic sites may have a more complex functional relationship, such as Chaetogaster limnei, which lives in association with gastropods in Baldoví.

Each studied wetland had a quite distinct fauna. The sites differed broadly in environmental characteristics, such as salinity and hydrology and this was reflected in community composition. In the present work, as in others where study sites differed in salinity conditions (Arnolds \& Ormerod, 1997; Bayo, 2001), the main ecological factor responsible for species composition was salinity. This was reflected in the PCA analysis, which clearly separated saline from freshwater sites on the first two axes. In permanent freshwater sites (Xeresa and Cap de Terme) the community was composed of swimming insect larvae (both predators, such as
Odonata, and collectors, like Ephemeroptera), whereas in Albufera and Baldovi Oligochaeta and Gastropods were more important.

Chironomids, the most abundant invertebrates in the samples, had distinct species assemblages which could be related to environmental quality assessment. The species found are known as epiphytes and have widespread distribution (Armitage et al., 1995). C. sylvestris had been considered tolerant to eutrophication (Verneaux et al., 2004) and chironomid stratigraphy studies relate this species with high total phosphorus levels (Langdon et al., 2006). High densities of this species were found in the most eutrophic sites. In the hypertrophic Albufera C. sylvestris was abundant altogether with Chironomus gr. luridus. In Cap de Terme, which is a eutrophic lake but still has a good macrophyte coverage, although $C$. sylvestris was abundant the chironomid community was more diverse. Meanwhile, in the oligotrophic permanent freshwater site, Baldoví, this species was also present but in much lower densities, indicating its broad tolerance to environmental conditions.

Xeresa, which is a semi-permanent freshwater site of low trophic state, was differentiated by the presence of the tanypod Ablabesmyia monilis, a predator that has been observed with remains of Cricotopus flavocinctus in their guts. Moreover, in chironomid stratigraphy studies Langdon et al. (2006) related this species with low total phosphorus levels. Other studies also found the Tanypodinae family to be a good quality indicator (Trigal, 2006), although some deep benthonic species can tolerate low dissolved oxygen levels, like Procladius (Prat \& Rieradevall, 1995). In a mesocosm experimental study performed in a close-by pond in the same protected area, the addition of nutrients reduced Tanypodinae abundance and enhanced Ortocladiine development in a year of low water level, while in a year with higher water levels, nutrient enhanced the growth of a Chironomus population (Miracle et al., 2006).

The brackish sites differ in their water chemistry and trophic state. Cabanes, near the sea shore, may be considered as a truly brackish site, because its ion composition is characteristic of 
diluted marine water, while Hondo has a higher sulphate/chloride ratio than Cabanes. The southernmost and warmest site, Hondo, receives quite saline inflows from irrigation runoff and, high evaporation rates in this water body, concentrates these salts even more. They also differ in trophic state, Cabanes being the more oligotrophic. Although both sites share the same crustacean species, the chironomid community was quite different as we commented previously.

The sampling method used proved suitable for obtaining quantitative and comparable data of invertebrate abundance in a variety of shallow lakes, despite their clear or turbid state. Furthermore, the macroinvertebrate densities can be related to trophic status when the study sites are similar in both hydrology and salinity. The species composition of the macroinvertebrate communities in reed-beds reflects the different environmental features of the lakes studied, especially chironomids, which are the main group characteristic of this habitat. A study with the same methodology (Cañedo-Argüelles \& Rieradevall, 2007) in other coastal shallow lakes found that Chironomids in reed-beds were the most abundant taxa, averaging $79 \%$ of total density and representing $44 \%$ of total taxa richness.

\section{REFERENCES}

ARMITAGE, P., P. S. CRANSTON \& L. C. V. PINDER (eds.). 1995. The Chironomidae. Chapman \& Hall. 572 pp.

ARNOLD, S. L. \& S. J. ORMEROD. 1997. Aquatic macroinvertebrates and environmental gradients in Phragmites reedswamps: implications for conservation. Aquatic Conservation: Marine and Freshwater ecosystems, 7: 153-163.

BAYO, M., M. ORTEGA, P. LANGTON \& J. J. CASAS. 2001. Evaluación ecológica de humedales y la Directiva marco del Agua: sobre el valor indicador de las comunidades de dípteros quironómidos en los humedales litorales de la provincia de Almería. Actas V Simposio sobre el Agua en Andalucía, Almería: 375-384.

BLANCO, S., S. ROMO, M. J. VILLENA \& S. MARTÍNEZ. 2003. Fish communities and food web interactions in six shallow Mediterranean lakes. Hydrobiologia, 506-509: 473-480.

CAÑEDO-ARGÜELLES, M. 2006. Macroinvertebrate communities associated to Phragmites australis in 11 shallow lakes of Llobregat's river delta (Catalonia, Spain). Diploma de Estudios Avanzados en Ecología Fundamental y Aplicada. Universidad de Barcelona. $30 \mathrm{pp}$.

DVORAK, J. \& E. P. H. BEST. 1982. Macroinvertebrate communities associated with the macrophytes of La Vechten: structural and functional relationships. Hydrobiologia, 95: 115-126.

GARCÍA-CRIADO, F. \& C. TRIGAL. 2005. Comparison of several techniques for sampling macroinvertebrates in different habitats of a North Iberian pond. Hydrobiologia, 545: 103-115.

HIRVENOJA, M. 1973. Revision der Gattung Cricotopus van der Wulp und ihrer Verwandten (Diptera, Chironomidae). Ann. Zool. Fennici, 10: 1-363.

KORNIJÓW, R. 1989. Macrofauna of elodeids of two lakes of different trophy. I. Relationships between plants and structure of fauna colonizing them. Ekologia Polska, 37 (1-2): 31-38.

KORNIJÓW, R. \& T. KAIRESALO. 1994. A simple apparatus for sampling epiphytic communities associated with emergent macrophytes. Hydrobiologia, 294: 141-143

LANGDON, P. G., Z. RUIZ, K. P. BRODERSEN \& I. D. L. FOSTER. 2006. Assessing lake eutrophication using chironomids: understanding the nature of community response in different lake types. Freshwat. Biol., 51: 562-577.

LANGTON, P. H. 1991. A Key to pupal exuviae of West Palaearctic Chironomidae. P. H. Langton (Ed.). Cambridgeshire. 386 pp.

LEARNER, M. A., G. LOCHHEAD \& B. D. HUGHES. 1978. A review of the biology of British Naididae with emphasis on the lotic environment. Freshwat. Biol., 8: 357-375.

MIRACLE, M. R., B. MOSS, E. VICENTE, S. ROMO, J. RUEDA, E. BECARES, C. FERNÁNDEZALÁEZ, M. FERNÁNDEZ-ALÁEZ，J. HIETALA, T. KAIRESALO, K. VAKKILAINEN, D. STEPHEN, L. A. HANSSON \& M. GYLLSTRÖM. 2006. Response of macroinvertebrates to experimental nutrient and fish additions in European localities at different latitudes. Limnetica, 25 (1-2): 585-612.

MOSS, B., D. STEPHEN, C. ALVAREZ, E. BECARES, W. VAN DE BUND, S. E. COLLINGS, 
E. VAN DONK, E. DE EYTO, T. FELDMANN, C. FERNÁNDEZ-ALÁEZ, M. FERNÁNDEZALÁEZ, R. J. M. FRANKEN, F. GARCÍACRIADO, E. M. GROSS, M. GYLLSTROM, L. A. HANSSON, K. IRVINE, A. JÄRVALT, J. P. JENSEN, E. JEPPESEN, T. KAIRESALO, R. KORNIJÓW, T. KRAUSE, H. KÜNNAP, A. LAAS, E. LILL, B. LORENS, H. LUUP, M. R. MIRACLE, P. NOGES, T. NOGES, M. NYKÄNEN, I. OTT, W. PECZULA, E. PEETERS, G. PHILLIS, S. ROMO, V. RUSSELL, J. SALUJOE, M. SCHEFFER, K. SIEWERTSEN, H. SMAL, C. TESCH, H. TIMM, L. TUVIKENE, I. TONNO, T. VIRRO, E. VICENTE \& D. WILSON. 2003. The determination of ecological status in shallow lakes- a tested system (ECOFRAME) for implementation of the European Water Framework Directive. Aquatic Conservation: Marine and Freshwater Ecosystems, 13: 507-549.

OERTLY, B. \& J. B. LACHAVANNE. 1995. The effects of shoot age on colonization of an emergent macrophyte (Typha latifolia) by macroinvertebrates. Freshwat. Biol., 34: 421-431.

PIECZYŃSKA, E., A. KOŁODZIEJCZYK \& J. I. RYBAK. 1999. The response of littoral invertebrates to eutrophication-linked changes in plant communities. Hydrobiologia, 391: 9-21.

POQUET, J. M., F. MEZQUITA, J. RUEDA \& M. R. MIRACLE. 2008. Loss of Ostracoda biodiversity in Western Mediterranean wetlands. Aquatic Conservation: Mar. Freshw. Ecosyst., 18: 280-296.

PRAT, N. \& M. RIERADEVALL. 1995. Life Cycle and Production of Chironomidae from the Karstic Lake Banyoles (NE Spain). Freshwat. Biol., 33: 511-524.

SAHUQUILLO, M., J. M. POQUET, J. RUEDA \& M. R. MIRACLE. 2007. Macroinvertebrate com- munities in sediment and plants in coastal Mediterranean water bodies (Central Iberian Peninsula). Ann. Limnol.-Int. J. Lim., 43 (2): 117-130.

SCHMID, P. E. 1993. A key to the larval Chironomidae and their instars from Austrian Danube region streams and rivers with particular reference to a numerical taxonomic approach. Part I. Diamesinae, Prodiamesinae and Orthocladiinae. Wasser und Abwasser Supplement, 3/93: 1-514.

SCHNELL, O. A., M. RIERADEVALL, I. GRANADOS \& O. HANSSEN. 1999. A Chironomid taxa coding system for use in ecological and palaeoecological databases. NIVA REPORT No. 3710-97, Molar Project Manual, Annex B. 19 pp.

TRIGAL, C. 2006. Evaluación del estado ecológico de las lagunas esteparias de la Depresión del Duero: ¿Son los macroinvertebrados buenos indicadores?. Tesis Doctoral. Universidad de León. 242 pp. VAN DE MEUTTER, F., R. STOKS \& L. DE MEESTER. 2005. The effect of turbidity state and microhabitat on macroinvertebrate assemblages: a pilot study of six shallow lakes. Hydrobiologia, 542: 379-390.

VARGA, I. 2001. Macroinvertebrates in reed litter. Int. Rev. Hydrobiol., 86: 573-583.

VERNEAUX, V., J. VERNEAUX, A. SCHMITT, C. LOVY, \& J.C. LAMBERT. 2004. The Lake Biotic Index (LBI) : an applied method for assessing the biological quality of lakes using macrobenthos ; the Lake Châlain (French Jura) as an example. Ann. Limnol. Int. J. Lim., 40 (1): 1-9.

VICENTE, E. \& M. R. MIRACLE. 1992. The coastal lagoon Albufera de Valencia: An ecosystem under stress. Limnetica, 8: 87-100.

WIEDERHOLM, T. 1983. Chironomidae of the Holarctic region. Keys and diagnoses. Part 1. Larvae. Ent. Scand. Suppl., 18: 1-457. 